\title{
The Effect of Using Wikis on the Students' Reading Comprehension in Learning English
}

\section{| Morteza Bakhtiarvand |}

\author{
PhD candidate in Educational \\ Technology, Allameh \\ Tabataba'i University, Tehran, \\ Iran
}

m_bakhtiarvand@yahoo.com

\begin{abstract}
The aim of this study was to evaluate the impact of the use of wikis on the ability to understand semantic meaning of English. At the beginning of the study, a reading comprehension proficiency test was administered for two groups of students in order to determine the level of reading comprehension skills. Then the pre-test were given to the students of both control and experimental groups. After the pre-test, students in both groups for 6 weeks and every week for two hours were trained for learning English reading comprehension proficiency skills. The difference is that students in the control group were trained in traditional way and the students in experimental group were trained by using wikis. At the end of four weeks, the post test was administered for students in both groups. Four standard tools were used for data collection in this study. At first reading comprehension proficiency test was given to two groups in order to determine the level of reading comprehension skills. The second tool was a test that was used as pre-test, post-test and delayed post-test. The third instrument was reading comprehension texts that were selected from different sites of Wiki (e.g., Wikipedia, Wiki Facebook, wiki, wiki Dick, Wiki News) in both form of offline and online will be available to students. The fourth instrument was Systematic Functional Grammar (SFG) scale for difficulty level of texts (Shokrpour, 2004). The descriptive statistics indicators such as frequency, mean and standard deviation of scores and in the inferential part in order to examining the hypothesis, one-way analysis of covariance (ANCOVA) was used. The results showed that the use of wikis increase the ability to understand the semantic meaning of words. KEYWORDS

Wikis; Reading Comprehension; English Reading Texts; Student.
\end{abstract}

\section{INTRODUCTION}

Since the 1990s, following the rapid growth of technology, teachers have sought to create classrooms equipped with a variety of devices using multimedia technology, so there have been significant changes in the use of computers in learning. This made students interested in learning. Spontaneous learning among students has led researchers to apply new ways of using modern technology and the web in learning. With the advent of Web 1, Web 2, and the newer Web 3, teachers have focused more on Internet-related tools than anything else (Polleti, A, \& Freitag, B, 2011).

Wiki Internet sites widely allow their users to easily operate and participate in an educational environment. Their main use is to evolve pages around a theme, and one of the most popular examples is Wikipedia. This type of wiki internet space is based on similar ideas and hypotheses, such as the wiki encyclopedia (Bruns, A. \& Humphreys, S., 2005). Education wikis include WikiEducator and Wikipedia's scientific encyclopedia. Each of these includes areas such as discussion, deep communication between participants, group 
writing, and group document creation. This category indicates the boundaries of the textures and spaces in which wiki spaces are used.

Wiki has become popular because of its ease of use and rapid growth, providing an opportunity for strong information sharing, and covering collaborative writing and reading activities, as well as improving student relationships (Boulous, M., Maramba, I., \& Wheeler, S.., 2006). Arreguin, C. (2004) notes that "Wiki provides unique collaborative opportunities in training and easy integration of existing information, providing fast feedback, facilitated HTML, and simultaneous access to multiple editors. Wiki has been able to very quickly and be creative in providing information. Also, wiki has brought together users' ideas, and developed active online relationships on the web (Wang, H., Lu, C., Yang, J., Hu, H., Chiou, G., Chiang, Y., et al., 2005)

One of the reasons that wiki internet spaces are commonly used in educational institutions is their ease of use and on the other hand their low cost. Learning how to use these spaces is easy and creating new scientific content in these spaces is not time consuming. The focus is not only on the content of the remaining content and the software itself. All participants have an equal right, meaning that any user can edit or add content at any time. This indicates a particular intuitive state of change in students' interaction with the subjects (Holzinger, 2008).

With the exception of a handful of people interested in the social and group dimensions of the wiki, to date there has been little attention to the actual use of wiki spaces with a style of thinking and acting with science and knowledge. In addition, a new understanding is felt by users about the social models and rational references that evolve wiki. How does such a mindset emerge coherently in the course of work processes, and especially in an academic context (Fuchs-Kittowski, F. \& Kohler, A., 2005)? In a wiki environment, to what extent do we need "thought methods" for students to participate in teaching and learning ?

\section{Using Wikis in Teaching and Learning}

Wiki is believed to have provided a kind of private online space to support student group activities (Beldarrain, Y., 2006). This online space allows people to collectively create, modify, and edit web pages that place more emphasis on content. This internet space can be used as a place for mental evacuation and a place for archiving shared information and communication with other links. Unlike blogs, which are organized in chronological order and edited by only one person, such Internet spaces can be used and edited by all members and are therefore often used to enhance the content of group information (Goodwin-Jones, R., 2003). ). Online wiki spaces give users power of action and ownership, and on the other hand, promote students' sense of responsibility for teaching and learning in a calm and favorable environment. Research suggests that a wiki can be a common and friendly space for users to participate, generate knowledge, store information and create some kind of interaction.

It seems that language experts should look for content, assignments and texts that are fully in line with the activities and principles mentioned. There are many cases in this field, for example, we can mention the content that is of linguistic, audio, movement and video importance and can be printed, audio, video or on CD through live performance and Or broadcast over the Internet (Richards, 2003). The emergence of new technologies has created hope and motivation for this field in terms of potentials that these tools can provide in the field of language learning methods that are largely in line with the principles of language teaching and learning.

This type of multilingual, web-based encyclopedia Wikipedia represents a prototype of group potential in the wiki environment. Its quality is extremely high and even anyone can 
participate in it and change articles and texts (Giles, 2005). Research on the educational use of this environment has increased in recent years. Theoretical aspects differ here, and generally Wikipedia is considered a good tool to facilitate the constructive and social processes associated with teaching and learning. It is also claimed here that these theoretical aspects challenge the conventional educational hypotheses about teaching reading and writing (Lundin, R. 2008). This is done by facilitating credible editing and reading categories.

It can be said that there is no research that can examine the educational potential of Wikipedia for learning (Elgort, I., Smith, A. G., \& Toland, J., 2008). Some research also shows that group reading is more of an exception than a norm (Lin, H. \& Kelsey, K. D., 2009). Hence, this is a challenging idealistic hypothesis, according to which Wikipedia is naturally useful. Experimental research usually focuses on how people work in the Wikipedia environment. The limited research that has been done in this direction is also mostly prescriptive.

\section{RESEARCH METHODS}

According to its objectives, this research is an applied research. Therefore, by examining the use of wikis in comprehension of English students in the third grade of high school, it tries to provide a planning environment for them to increase their comprehension skills in English texts. Methodologically, this study is part of experimental research. One of the types of experimental designs is pre-test, post-test and post-test design related to the control group that the researcher can randomly assign the subjects to the experimental groups and examine the effect of the independent variable on the dependent variable. In this experimental design, first the subjects are selected and then they are divided into experimental groups in such a way that the conditions before the experiment are the same for them. Then, by manipulating the independent variable, the effect of the experimental operation on the dependent variable is studied. In this study, pre-test and post-test experimental design with control group was used.

\section{Statistical Population}

According to this sampling method in this study, random sampling was done, so the researcher randomly selected Shahid Chamran High School from all boys' high schools in Andimeshk city and two third and third grade mathematics and physics classes were randomly selected from among its classes. Therefore, the population of this study included the third year male students of Chamran Andimeshk High School in Mathematics and Physics. The number of these students was 80 , who were randomly divided into 2 classes of 40 people. Due to the randomness of the target population, the results of this study can be generalized to all other similar communities in terms of gender, educational level and educational level.

\section{Research Instruments}

To collect the data of the present study, 4 standard tools have been used.

1. At first, people from both groups will be taken comprehension test to determine the level of reading skills. This test has 25 multiple choice questions. The reliability of this test was calculated based on the Corder-Richardson method (KR-21) and the reliability was 0.732 , which indicates the high reliability of the test. The first step in determining test validity is to check the content validity. Content validity depends on the logical analysis of the content of a test and its determination is based on subjective and individual judgment. In this method, the test questions were given to the experts or 
some of the subjects and they were asked to determine whether the test questions measure the desired trait or not and whether the questions cover the entire content of the test. Take it or not. And due to the fact that there was agreement between different people about the validity of the test, this test has a high content validity. This test is selected from the TOEFL Readiness Book (Sharp, 2014).

2. The second research tool is a test that is not used as a pre-test, post-test and delayed post-test (a test that is used after two weeks to measure the stability of training effects is in fact the same test that is used as a pre-test and post-test) is used. This excerpt from TOEFL Exam (Susan Bates, 2016) has 45 four-choice questions that measure the first 15 questions of vocabulary comprehension and the ability to recognize the meaning of words separately from the text. The second 15 questions are Cloze Passage, meaning the incomplete texts that the student must use the words above to complete the semantic structure of the text, and finally the last 15 questions, which are comprehension texts and questions are extracted from these texts. At the end of each text. The reliability of this test was calculated based on the Kuder-Richardson method (KR-21) and the reliability was 0.732 , which indicates the high reliability of the test. The first step in determining test validity is to check the content validity. Content validity depends on the logical analysis of the content of a test and its determination is based on subjective and individual judgment. In this method, the test questions were given to the experts or some of the subjects and they were asked to determine whether the test questions measure the desired trait or not and whether the questions cover the entire content of the test. Take it or not. And due to the fact that there was agreement between different people about the validity of the test, this test has a high content validity.

3. The third tool is texts related to comprehension, which has been selected from various wiki sites (e.g., Wikipedia, Wikibooks, Wikisource, WikiLeaks, Wiki News) to examine the impact of wikis on people's comprehension ability. And will be available to students both offline and online. The level of difficulty of these reading texts has been determined based on the criterion for determining the purposeful grammatical role (Shokrpour 2004) and they are considered suitable for third grade high school students.

4. The fourth criterion for determining the role of purposeful grammar has been identified (Shokrpour, 2004) according to which the difficulty of texts taken from different wiki sources is measured in terms of grammar and vocabulary than texts that are at the level of third grade high school students. Be selected. . The point of interest in these texts is to examine the level of difficulty, the presence of words and grammatical points in such texts, which in the present study has been evaluated and determined by the scale of "functional grammar to measure the difficulty of texts" (Shokrpour, 2004).

Of course, it should be noted that this scale consists of four parts:

1. Lexical Density

2. Grammatical Intricacy

3. Complex Nominal Group Structure

4. Grammatical metaphor

All texts used in this research have been evaluated by the researcher and the same level of high school students has been used.

\section{RESULTS AND DISCUSSION}

At the beginning of the study, all students in the two groups took a comprehension test to determine the level of reading skills. Then students from both control and pre-test groups 
were tested. After the pre-test, students in both groups were taught English comprehension for 6 weeks and for two hours each week. The difference is that the students in the control group were taught in the traditional way, i.e. the selected texts from the wiki sites were printed and given to the students on paper, and the students in the experimental group were taught using the wikis in this way. The texts were made available to students online and on the smart whiteboard or desktop computers in the classroom, and students could use the software features available on the wiki, such as an online dictionary, meta-links for further explanation, images, and more. Even use the correct pronunciation of words. At the end of the 6-week period, post-test was performed in both groups. Finally, after two weeks, the test was not performed.

Using wikis will increase the ability of male students to understand English in the third year of high school. In order to evaluate the effectiveness of using wikis on improving the ability to understand the correct meaning of students' words, the analysis of covariance was used. The results related to the implementation of this test and the examination of its assumptions separately to review the results of the post-test and follow-up stages are presented below.

Table1. Results of Kolmogorov-Smirnov test to check the normality of the distribution of scores

\begin{tabular}{|l|c|c|c|}
\hline \multicolumn{1}{|c|}{ Variable } & Number & $\begin{array}{c}\text { Kolmogorov } \\
\text { Smirnov }\end{array}$ & $\begin{array}{c}\text { The significance } \\
\text { level }\end{array}$ \\
\hline Pre-test of semantic comprehension ability & 80 & 0.988 & 0.283 \\
\hline Post-test the ability to understand semantics & 80 & 1.201 & 0.112 \\
\hline Pursue the ability to understand semantics & 80 & 1.240 & 0.092 \\
\hline
\end{tabular}

Table1 shows the results of the Kolmogorov-Smirnov test to check the normality of the distribution of pre-test and post-test scores. Based on the results in the table, the significance level of the calculated statistic for all variables is greater than 0.05 , so the assumption of normal distribution of pre-test and post-test scores is accepted.

\section{Post-test Phase}

Table2. Analysis results of uniformity of regression line slope as a default of analysis of covariance

\begin{tabular}{|c|c|c|c|c|c|}
\hline $\begin{array}{c}\text { Source of } \\
\text { changes }\end{array}$ & Total squares & $\begin{array}{c}\text { Degrees of } \\
\text { freedom }\end{array}$ & $\begin{array}{c}\text { Average } \\
\text { squares }\end{array}$ & $\begin{array}{c}\text { The value of } \\
\text { F }\end{array}$ & $\begin{array}{c}\text { Significance } \\
\text { level }\end{array}$ \\
\hline $\begin{array}{c}\text { Pre-test } \\
\text { group }\end{array}$ & 4.103 & 1 & 4.103 & 3.815 & 0.054 \\
\hline
\end{tabular}

Table 2 shows the results of the analysis of the uniformity of the regression line slope as the main premise of the analysis of covariance. Based on the results, the significance level of the group interaction line and pre-test $(p=0.054)$ is greater than 0.05 . Therefore, the regression homogeneity hypothesis is accepted.

Table3. Levin test result for homogeneity of variance

\begin{tabular}{|c|c|c|c|c|}
\hline Variable & $\mathrm{F}$ & Degree of Freedom & $\begin{array}{c}\text { Degree of } \\
\text { Freedom }\end{array}$ & $\begin{array}{c}\text { Significance } \\
\text { level }\end{array}$ \\
\hline $\begin{array}{c}\text { Ability to } \\
\text { understand } \\
\text { semantics }\end{array}$ & 0.143 & 1 & 78 & 0.706 \\
\hline
\end{tabular}

As shown in Table 3 Levin test results are not significant. Therefore, our null hypothesis that the variance is homogeneous with the variables is confirmed. Thus, the assumption of homogeneity of variances is established. 
Table 4. One-way analysis of covariance to compare the ability of semantic comprehension of the experimental and control groups in the post-test phase

\begin{tabular}{|c|c|c|c|c|c|c|}
\hline $\begin{array}{c}\text { Source of } \\
\text { variance }\end{array}$ & $\begin{array}{c}\text { Total } \\
\text { squares }\end{array}$ & $\begin{array}{c}\text { Degrees of } \\
\text { freedom }\end{array}$ & $\begin{array}{c}\text { Average of } \\
\text { squares }\end{array}$ & $\mathrm{F}$ & $\begin{array}{c}\text { Significance } \\
\text { Level }\end{array}$ & $\begin{array}{c}\text { Coefficient } \\
\text { Eta }\end{array}$ \\
\hline Pre-test & 193.258 & 1 & 193.258 & 173.351 & 0.001 & 0.692 \\
\hline Group & 21.513 & 1 & 21.513 & 19.297 & 0.001 & 0.200 \\
\hline Error & 85.842 & 77 & 1.115 & ......... & $\ldots \ldots \ldots$ & .. \\
\hline Total & 305.550 & 79 & & & & \\
\hline
\end{tabular}

The table 4 shows the results of the analysis of covariance test to compare the semantic comprehension scores of students in the experimental group and the control group in the post-test. The value of $\mathrm{F}$ is equal to 19.297 and its significance level is less than 0.01. Therefore, the null hypothesis is rejected and the research hypothesis is confirmed. Based on this, and considering the higher average scores of the experimental group in the post-test stage, it can be concluded that the use of wikis is effective and improves the semantic comprehension ability of third year high school male students.

\section{The Delayed post-test Phase}

Table5. Results of analysis of the same slope of the regression line as the default of analysis of covariance

\begin{tabular}{|c|c|c|c|c|c|}
\hline $\begin{array}{c}\text { Source of } \\
\text { changes }\end{array}$ & Total squares & $\begin{array}{c}\text { Degrees of } \\
\text { freedom }\end{array}$ & $\begin{array}{c}\text { Average } \\
\text { squares }\end{array}$ & $\begin{array}{c}\text { The value of } \\
\mathrm{F}\end{array}$ & $\begin{array}{c}\text { Significance } \\
\text { level }\end{array}$ \\
\hline $\begin{array}{c}\text { Pre-test } \\
\text { group }\end{array}$ & 1.462 & 1 & 1.462 & 1.834 & 0.180 \\
\hline
\end{tabular}

Table 5 shows the results of the analysis of the uniformity of the regression line slope as the main default for performing covariance analysis. Based on the results, the significance level of the group interaction line and pre-test $(\mathrm{p}=0.80)$ is greater than 0.05 . Therefore, the regression homogeneity hypothesis is accepted.

Table 6. Levin test result for homogeneity of variance

\begin{tabular}{|c|c|c|c|c|}
\hline Variable & F & $\begin{array}{c}\text { Degree of } \\
\text { Freedom }\end{array}$ & $\begin{array}{c}\text { Degree of } \\
\text { Freedom }\end{array}$ & $\begin{array}{c}\text { Significance } \\
\text { level }\end{array}$ \\
\hline Ability to understand semantics & 0.872 & 1 & 78 & 0.353 \\
\hline
\end{tabular}

As shown in Table 6, the results of the Levin test are not significant. Therefore, our null hypothesis that the variance is homogeneous with the variance is confirmed. Thus, the assumption of homogeneity of variances is established.

Table 7. One-way analysis of covariance to compare the semantic comprehension ability of the experimental and control groups in the follow-up phase

\begin{tabular}{|c|c|c|c|c|c|c|}
\hline $\begin{array}{c}\text { Source of } \\
\text { variance }\end{array}$ & $\begin{array}{c}\text { Total } \\
\text { squares }\end{array}$ & $\begin{array}{c}\text { Degrees of } \\
\text { freedom }\end{array}$ & $\begin{array}{c}\text { Average of } \\
\text { squares }\end{array}$ & $\mathrm{F}$ & $\begin{array}{c}\text { Significance } \\
\text { level }\end{array}$ & $\begin{array}{c}\text { Coefficient } \\
\text { Eta }\end{array}$ \\
\hline Pre-test & 252.138 & 1 & 252.138 & 312.950 & 0.001 & 0.803 \\
\hline Group & 11.141 & 1 & 11.141 & 13.829 & 0.001 & 0.152 \\
\hline Error & 62.037 & 77 & 0.806 & $\ldots \ldots$ & $\ldots \ldots \ldots \ldots$ & $\ldots \ldots \ldots \ldots$ \\
\hline Total & 329.488 & 79 & $\ldots \ldots \ldots \ldots$ & $\ldots \ldots \ldots$ & $\ldots \ldots \ldots \ldots$ & $\ldots \ldots \ldots \ldots$ \\
\hline
\end{tabular}

Table 7 shows the results of the analysis of covariance test to compare the scores of semantic comprehension ability of students in the experimental group and the control group in the follow-up stage. The obtained $\mathrm{F}$ value is equal to 13.829 and its significance level is less than 0.01. Therefore, the null hypothesis is rejected and the research hypothesis is confirmed. Based on this, and considering the higher average scores of the experimental group in the follow-up phase, it can be concluded that the use of wikis is effective and improves the semantic comprehension ability of third year high school male students. 
Table 4 shows the results of the analysis of covariance test to compare the semantic comprehension scores of students in the experimental and control groups in the post-test. The value of $F$ is equal to 19.297 and its significance level is less than 0.01 . Therefore, the null hypothesis is rejected and the research hypothesis is confirmed. Based on this, and considering the higher average scores of the experimental group in the post-test stage, it can be concluded that the use of wikis is effective and improves the semantic comprehension ability of third year high school male students.

One of the most important reasons for this is that the use of wiki software and the creation of collaborative learning opportunities enable learners to access the knowledge of other learners in the shortest possible time and to be more successful in understanding the meaning of English texts. Because the more vocabulary a person has, the more successful he or she will be in understanding the meaning of English texts.

The results of the study of this research hypothesis, with the results of the researches of Al-Kahtani, S. A. (2001), Dela Cal-Fasoni, L.(2001), Kendra Sue, H. (2001), Almekhlafi, A. (2006), Tajjeddin and Nemati Sorkhi (2012), Azeri Nia And Daronkalaei (2012), and Hosseini Nasab, Gol Mohammadnejad and Sajedifar (2010) are in harmony. In their research, the researchers concluded that the use of Internet tools and web-based learning methods in teaching English increases the level of knowledge and comprehension along with students' interest, motivation and academic achievement

\section{CONCLUSION}

Today, most English teachers are not only concerned with how to teach in their classrooms, but also have many problems in preparing students to take on the responsibility of learning outside the classroom. If students take responsibility for their own learning, both in the learning environment and outside the learning environment, it will increase their learning and they will certainly become effective and efficient learners (Pinkman, K., 2005).

With the advent of information and communication technologies and integration with the curriculum, it has provided the ground for creating desirable educational facilities. Information and communication technologies have various communication tools such as wiki, blog, podcast, newsgroups, chat rooms, etc. that have the ability to influence the teaching-learning process (Brown, 2003). The present study examined the effect of using wikis on the English language comprehension rate of third grade high school male students and the results showed that the use of wikis has increased the English language comprehension rate of students. Also, the results of this study showed that the use of wikis in teaching English has increased the ability to understand and recognize the correct meaning of words, the ability to recognize appropriate words to complete incomplete texts and increase the semantic understanding of English texts.

\section{REFERENCES}

Al-Kahtani, S. A. (2001). Computer-Assisted language learning in EFL instruction at selected Saudi Arabian Universities: Progiles of faculty. Unpublished doctoral dissertation, Indian University of Pennsylvania.

Almekhlafi, A. (2006). The effect of Computer-Assisted Language Learning (CALL) on United Arab Emirates EFL school students' achievement and attitude. Journal of Interactive Learning Research, 17(2), 121-142.

Arreguin، C. (2004). Wikis. In B. Hoffman (Ed.) ، Encyclopedia of Educational Technology.

Azeri need, Marzieh. And Hosseini Daronkalaei, Zahra. (1391). Investigating the effect of using Wikipedia in increasing students' comprehension learning of English texts in 
middle school female students in Babol. Quarterly Journal of Information and Communication Technology in Educational Sciences. 3 (1). 129-109.

Bates, S. (2016). TOEFL Exam. Oxford: Oxford University Press.

Beldarrain, Y. (2006). Distance education trends: Integrating new technologies to foster student interaction and collaboration. Distance Education, 27(2), 139-153.

Boulous، M.، Maramba، I.، \& Wheeler، S. (2006). Wikis، blogs and podcasts: A new generation of web-based tools for virtual collaborative clinical practice and education.

Brown, D. (2003). Developing Faculty to use Technology .Balton, Anker Publishing Company.

Bruns, A. \& Humphreys, S. (2005). Wikis in Teaching and Assessment: The M/Cyclopedia Project. In Proceedings of the International Symposium on Wikis, (San Diego, USA, 2005). Available at http://www.wikisym.org/ws2005/ proceedings/paper-03.pdf.

Dela Cal-Fasoni, L. (2001). A technology to enhance teaching and learning. Front row phonics: Acal filed test, Mal. California State University.

Elgort، I. ‘ Smith‘ A. G.، \& Toland، J. (2008). Is wiki an effective platform for group course work? Australasian Journal of Educational Technology، 24(2) ، 195-210.

Giles, J. (2005). Internet encyclopedias go head to head. Nature, 438, 900-901.

Goodwin-Jones, R. (2003). Blogs and wikis: Environments for on-line collaboration. Language Learning \& Teaching, 7, 12-16.

Holzinger, A. (2008).HCI and Usability for Education and Work. Austria: Springer.

Hosseini Nasab, Davood, Gol Mohammadnejad, Gholamreza. And Sajedifar, Yousef. (1389). Investigating the effect of using Wikipedia on academic achievement and students' interest in learning English comprehension. Journal of Educational Sciences. 3 (10). 67-41

Kendra Sue, H. (2001). A descriptive analysis of a computer assisted instruction development English program. DAL-A 62/10, P.3283.

Lin، H. \& Kelsey، K. D. (2009). Building a networked environment in wikis: the evolving phases of collaborative learning in a wiki book project. Journal of Educational Computing Research، 40(2) ، 145-169.

Lundin, R. (2008). Teaching with wikis: Toward a networked pedagogy. Computers and Composition, 25(4), 432-448.

Pinkman, K. (2005) the JALT CALL Journal, 2005, Vol. 1, No. 1, pp. 12-24

Polleti ‘ A \& \& Freitag، B. (2011). Designing an e-learning platform for reading comprehension.

Richard, J. C. (2003). Second Language Writing. Ken Hyland: Cambridge Language Education.

Sharp، P. J. (2014). How to practice for the TOEFL. (10th Ed.).London: Barron's Educational Inc.

Shokrpour, Nasrin. (1383). Systematic functional grammar scale for measuring the difficulty of texts. Journal of English Language Teaching in India. 12 (30). 26-5

Tajjeddin, Zia Uddin. And a red blessing, beloved. (1391). Investigating the effect of computer-based education in comparison with the traditional method on the learning rate of non-Persian language learners. Persian language teaching research paper for nonPersian speakers. 1 (1). 132-111

Wang، H.، Lu، C.، Yang، J.، Hu، H.، Chiou، G.، Chiang، Y.، et al. (2005). An empirical exploration of using wiki in English as a Second Language course. Paper presented at the fifth IEEE International Conference on Advanced Learning Technologies: 155-157، (ICALT، 05).

Wikipedia (2008). Wikipedia. Retrieved March 3, 2008 from http://en.wikipedia.org/wiki/Wikipedia

Woods, D. and Thoeny, P. (2011). Wikis for Dummies. Indianapolis: Wiley Publishing, Inc. 